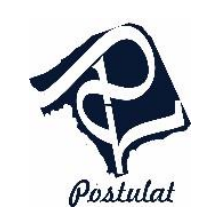

Jurnal Inovasi Pendidikan Matematika

Volume 1, Nomor 2, Desember 2020

\title{
Meningkatkan Keaktifan Peserta Didik Pada Kelas XI TBG 1 SMKN3 Jember Melalui Aplikasi Google Classroom
}

\author{
Sevi S Addine \\ SMK Negeri 3 Jember; Jl. DR. Soebandi, Kreongan Atas, Jemberlor, Kec. Patrang, Kabupaten Jember, Jawa \\ Timur 68118; seviaddine4@gmail.com,
}

\begin{abstract}
This research is a Classroom Action Research $(C A R)$ which aims to increase the learning activeness of students through the Google Classroom application. The subjects in this study were 33 students of class XI TBG 1 SMK Negeri 3 Jember. Data collection techniques in this research include observation, tests. Active learning through the Google Classroom application is carried out in 2 cycles consisting of the planning stage, the implementation stage, the observation stage and the reflection stage. The results of the study in cycle 1 showed that the class average value obtained was $66.3 \%$, after being given action in cycle II using an innovative learning model, the learning outcomes increased with a class average score of $75 \%$ with 31 students who completed. . These results indicate that there is an increase in student learning outcomes using the google classroom application, so it can be concluded that student learning activity also increases.
\end{abstract}

Keywords: Google, Classroom, Liveliness

\begin{abstract}
Abstrak
Penelitian ini merupakan Penelitian Tindakan Kelas (PTK) yang bertujuan untuk meningkatkan keaktifan belajar peserta didik melalui aplikasi Google Classroom. Subjek dalam penelitian ini adalah 33 siswa kelas XI TBG 1 SMK Negeri 3 Jember. Teknik pengumpulan data pada peneliltian ini meliputi observasi, tes. Keaktifan belajar melalui aplikasi Google Classroom dilakukan dalam 2 siklus yang terdiri dari tahap perencanaan, tahap pelaksanaan, tahap observasi dan tahap refleksi. Hasil penelitian pada siklus 1 menunjukan nilai rata-rata kelas yang diperoleh sebesar 66,3\%, setelah diberikan tindakan pada siklus II dengan menggunakan model pembelajaran inovatif mengalami peningkatan hasil belajar dengan nilai ratarata kelas sebesar $75 \%$ dengan siswa yang tuntas sebanyak 31 siswa. Hasil ini menunjukan bahwa adanya peningkatan hasil belajar siswa dengan menggunakan aplikasi google classroom, sehingga dapat disimpulkan bahwa keaktifan belajar siswa juga meningkat.

Kata kunci: Google, Classroom, Keaktifan.
\end{abstract}


INFO ARTIKEL

ISSN :2733-0597

e-ISSN : 2733-0600

DOI : http://dx.doi.org/10.30587/postulat.v1i2.2110

\section{Jejak Artikel}

Submit Artikel:

2 Oktober 2020

Submit Revisi:

1 November 2020

Upload Artikel:

5 Desember 2020

\section{PENDAHULUAN}

Proses belajar mengajar yang baik dapat dipengaruhi oleh beberapa faktor, diantaranya pengajar atau guru, model pembelajaran, kondisi peserta didik dan sarana. Faktor yang paling besar pengaruhnya terhadap proses pembelajaran adalah pada guru itu sendiri. Guru harus mampu merancang dan melaksanakan suatu pembelajaran yang efektif sehingga tujuan pembelajaran dapat tercapai. Guru juga harus menciptakan suasana belajar yang menarik bagi peserta didik sehingga perhatian dan aktivitas mereka terpusat pada proses pembelajaran

Untuk mengatasi permasalahan tersebut perlu adanya perbaikan yang dilakukan oleh guru. Salah satunya pada model pembelajaran yang digunakan. Salah satu model pembelajaran yang dapat dijadikan alternatif adalah Model Discovery Learning dan Problem Based Learning yang merupakan model pembelajaran yang sesuai dalam pembelajaran inovatif abad 21. Model pembelajaran yang dapat membuat peserta didik berfikir kritis, berkolaborasi, berkomunikasi, dan berkreatifitas.

Melalui aplikasi Google Classroom pada pembelajaran daring sangat membantu guru dalam proses pembelajaran. Guru harus mampu membuat model dan strategi pembelajaran yang sesuai dengan karakter peserta didik di sekolahnya. Guru harus terbiasa mengajar dengan memanfaatkan media daring kompleks yang dikemas dengan efektif, mudah diakses, dan dipahami oleh peserta didik. Dengan demikian guru dituntut mampu merancang dan mendesain pembelajaran daring yang ringan dan efektif, dengan memanfaatkan perangkat atau media daring yang tepat dan sesuai dengan materi yang diajarkan. Walaupun dengan pembelajaran daring akan memberikan kesempatan lebih luas dalam mengeksplorasi materi 
Sevi S Addine : Meningkatkan Keaktifan Peserta Didik Pada Kelas...

yang akan diajarkan, namun guru harus mampu memilih dan membatasi sejauh mana cakupan materinya dan aplikasi yang cocok pada materi dan metode belajar yang digunakan.

Penggunaan Google Classroom ini sesungguhnya mempermudah guru dalam mengelola pembelajaran dan menyampaikan informasi secara cepat dan akurat kepada peserta didik Google Classroom dapat digunakan untuk membuat dan mengelola kelas, tugas, nilai serta memberikan masukan secara langsung. Peserta didik dapat memantau materi dan tugas kelas, berbagi materi dan berinteraksi dalam kelas atau melalui email, mengirim tugas dan mendapatkan masukan nilai secara langsung. Pembelajaran dengan penggunaan Google Classroom ini memiliki kelebihan untuk mempermudah peserta didik dalam belajar sehingga dapat meningkatkan hasil belajarnya. Namun pada realitanya, peserta didik kurang begitu antusias terhadap pembelajaran online melalui Google Classroom. Google Classroom tidak begitu dimanfaatkan dengan tepat di masa pandemi ini. Masih ada

peserta didik yang tidak mengikuti pembelajaran online, sehingga tugas menumpuk dan belum dikerjakan.

Berdasarkan uraian diatas rumusan masalah yang diajukan dalam penelitian tindakan kelas ini adalah : Bagaimana penggunaan aplikasi Google Classroom dapat meningkatkan keaktifan belajar peserta didik. Berdasarkan rumusan masalah diatas, tujuan penelitian tindakan kelas adalah : Meningkatkan keaktifan belajar Peserta Didik melalui aplikasi Google Classroom.

\section{METODE PENELITIAN}

Jenis penelitian yang dilaksanakan oleh peneliti adalah Penelitian Tindakan Kelas (PTK). Penelitian tindakan kelas dalam penelitian ini dimaksudkan untuk memperbaiki keaktifan belajar matematika peserta didik kelas

Pengambilan sampel berdasarkan "penilaian", peneliti mengenai siapa-siapa saja yang pantas memenuhi persyaratan untuk dijadikan sampel. Oleh karena itu latar belakang pengetahuan tertentu mengenai sampel dimaksud tentu juga populasinya agar benar-benar bisa mendapatkan sampel yang sesuai dengan persyaratan atau tujuan peneliti yang sehingga mendapat atau memperoleh data yang akurat. Dalam penelitian ini menggunakan subjek peserta didik kelas XI TBG 1 SMKN 3 Jember dengan jumlah 33 peserta didik, dengan rincian terdiri dari 6 peserta didik laki-laki dan 27 peserta didik perempuan. Alasan peneliti 
mengambil subjek penelitian ini yaitu dengan pertimbangan dari hasil-hasil observasi yang telah diuraikan pada latar belakang masalah.

\section{HASIL PENELITIAN}

Penelitian tindakan kelas ini bertujuan untuk meningkatan keaktifan belajar peserta didik pada kelas XI SMKN 3 Jember melalui aplikasi Google Classroom tahun pelajaran 2020/2021. SMK N 3 Jember terletak di Kab. Jember dan kelas yang dijadikan sebagai penelitian adalah kelas XI TBG 1 dengan jumlah 33 peserta didik, dengan rincian terdiri dari 6 peserta didik laki-laki dan 27 peserta didik perempuan. Selama masa pandemic, pembelajaran dilaksanakan secara online (dalam jaringan) sehingga dilakukanlah sebuah penelitian untuk dapat melihat keaktifan belajar peserta didik dalam pembelajaran online dengan menggunakan Google Classroom sebagai media pembelajaranya. Penelitian ini dilakukan sebanyak 3 kali tahapan penelitian siklus I, penelitian siklus II, dan penelitian siklus III. Pada siklus ini peneliti melakukan kegiatan pembelajaran, diskusi kelompok, presentasi kelompok dan mengerjakan soal individu. Soal individu yang nantinya akan dijadikan sebagai nilai hasil belajar pada siklus I, siklus II dan siklus III.

Tabel 1 Keaktifan Belajar

\begin{tabular}{|c|l|l|l|l|}
\hline No & \multicolumn{1}{|c|}{ Indikator } & $\begin{array}{l}\text { Jumlah } \\
\text { Siklus I }\end{array}$ & $\begin{array}{c}\text { Jumlah } \\
\text { Siklus II }\end{array}$ & $\begin{array}{l}\text { Jumlah } \\
\text { Siklus III }\end{array}$ \\
\hline 1 & $\begin{array}{l}\text { Memperhatikan power point dan } \\
\text { penjelasan yang diberikan guru pada } \\
\text { saat kegiatan pendahuluan }\end{array}$ & 25 & 30 & 29 \\
\hline 2 & $\begin{array}{l}\text { Mengisi Absen melalui Google } \\
\text { Classroom }\end{array}$ & 29 & 31 & 33 \\
\hline 3 & $\begin{array}{l}\text { Mengerjakan dan Mengumpulkan } \\
\text { LKPD }\end{array}$ & 28 & 33 \\
\hline 4. & $\begin{array}{l}\text { Bekerjasama dalam kelompok } \\
\text { kecilnya }\end{array}$ & 28 & 29 & 33 \\
\hline 5. & $\begin{array}{l}\text { Aktif pada saat diskusi kelompok } \\
\text { 6. kesimpulan dengan }\end{array}$ & $\begin{array}{l}\text { Membuat 26 } \\
\text { mengumpulkan refleksi di Google } \\
\text { Classroom }\end{array}$ & 31 & 33 \\
\hline 7. & $\begin{array}{l}\text { Mengumpulkan tugas yang } \\
\text { diberikan melalui Google Classroom }\end{array}$ & 28 & 28 & 33 \\
\hline
\end{tabular}


Sevi S Addine : Meningkatkan Keaktifan Peserta Didik Pada Kelas...

\begin{tabular}{|l|l|l|l|}
\hline Jumlah Nilai & 171 & 196 & 209 \\
\hline Jumlah Total & $7 \times 33=$ & $7 \times 33=$ & $7 \times 33=$ \\
231 & 231 & 231 \\
\hline
\end{tabular}

Skor perolehan lembar observasi keaktifan diskusi kelompok:

$$
P O=\frac{\sum O D K}{N O} \times 100 \%
$$

Keterangan:

PO : Presentase keaktifan belajar

$\sum O D K \quad$ : Jumlah skor indikator keaktifan belajar yang diperoleh

NO :Jumlah keseluruhan skor keaktifan belajar

Penggolongan kriteria keaktifan peserta didik dalam pembelajaran online adalah aktif.

Tabel 2. Kriteria Keaktifan Belajar Peserta didik

\begin{tabular}{|c|l|}
\hline \multicolumn{1}{|c|}{ Interval } & \multicolumn{1}{|c|}{ Kategori } \\
\hline $80 \%-100 \%$ & Sangat Aktif \\
\hline $60 \%-79 \%$ & Aktif \\
\hline $40 \%-59 \%$ & Cukup Aktif \\
\hline $20 \%-39 \%$ & Kurang Aktif \\
\hline $0 \%-19 \%$ & Tidak Aktif \\
\hline
\end{tabular}

Berdasarkan hasil observasi keaktifan peserta didik dalam pembelajaran online siklus I yaitu $74 \%$ dengan kategori aktif.Siklus II yaitu 84,84\% dengan kategori sangat aktif. SIklus III yaitu 90,47 \% dengan kategori sangat aktif.

Tabel 3. Kriteria Keaktifan Belajar Peserta didik Per Siklus

\begin{tabular}{|l|l|l|l|l|}
\hline No & Nama & Nilai I & Nilai II & Nilai III \\
\hline 1 & Adelia Nur & 70 & 100 & 100 \\
\hline
\end{tabular}




\begin{tabular}{|c|c|c|c|c|}
\hline 2 & Afila Zulfan & - & 50 & 90 \\
\hline 3 & Amalia & 70 & 40 & 70 \\
\hline 4 & Andhika & 70 & 50 & 80 \\
\hline 5 & Artha Fil'ard & - & 100 & 90 \\
\hline 6 & $\begin{array}{l}\text { Belgis } \\
\text { Andiana }\end{array}$ & 70 & 100 & 90 \\
\hline 7 & $\begin{array}{l}\text { Diana } \\
\text { Kholidah }\end{array}$ & 30 & 100 & 100 \\
\hline 8 & Erlangga Dwi & 100 & 40 & 80 \\
\hline 9 & Fani Zahra & 100 & 100 & 100 \\
\hline 10 & Felisya Refina & - & 40 & 70 \\
\hline 11 & Ferawati & 70 & 100 & 90 \\
\hline 12 & Filastin Nuril & 70 & - & 70 \\
\hline 13 & Hermione & 70 & 100 & 100 \\
\hline 14 & Jenny Eka & 70 & 100 & 100 \\
\hline 15 & $\begin{array}{l}\text { Khusnul } \\
\text { Ainur }\end{array}$ & 100 & 100 & 100 \\
\hline 16 & Lilik Hidayah & 30 & 100 & 90 \\
\hline 17 & $\begin{array}{l}\text { Lilis } \\
\text { Widayanti }\end{array}$ & 100 & 100 & 100 \\
\hline 18 & Maellya & - & 70 & 90 \\
\hline 19 & Maqri Rotus & - & 100 & 100 \\
\hline 20 & $\begin{array}{l}\text { Mar'i } \\
\text { Wajihanil }\end{array}$ & 70 & 70 & 100 \\
\hline 21 & Maulida Putri & - & 100 & 70 \\
\hline 22 & $\begin{array}{l}\text { Mahommad } \\
\text { Arif }\end{array}$ & 100 & 100 & 100 \\
\hline 23 & $\begin{array}{l}\text { Novasa } \\
\text { Nabila }\end{array}$ & 70 & 90 & 100 \\
\hline 24 & Nur Faizah & 70 & 100 & 90 \\
\hline 25 & Nurindah & - & - & 70 \\
\hline 26 & Putri Adelia & 70 & 100 & 100 \\
\hline 27 & Rani Mareza & 100 & 100 & 90 \\
\hline 28 & $\begin{array}{l}\text { Rival } \\
\text { Cahyono }\end{array}$ & 30 & 40 & 70 \\
\hline 29 & Vony Nur & 30 & 100 & 100 \\
\hline 30 & Widya & 30 & 100 & 90 \\
\hline 31 & $\begin{array}{l}\text { Yohana } \\
\text { Olivia }\end{array}$ & 70 & 100 & 100 \\
\hline 32 & Yosafah & 70 & 90 & 100 \\
\hline 33 & Yunita Ary & 70 & 100 & 100 \\
\hline
\end{tabular}


Sevi S Addine : Meningkatkan Keaktifan Peserta Didik Pada Kelas...

Rata-rata kelas hasil quis peserta didik yang sudah mengerjakan adalah 69,23 dari total 26 peserta didik untuk siklus I. Rata-rata kelas hasil quis peserta didik yang sudah mengerjakan adalah 86,45 dari total 31 peserta didik untuk siklus III. Rata-rata kelas hasil quis peserta didik yang sudah mengerjakan adalah 90,60 dari total 33 peserta didik untuk siklus III.

Tabel 4 Peningkatan Hasil Belajar Pada Setiap Siklus

\begin{tabular}{|c|c|c|c|c|}
\hline No & Keterangan & Siklus I & Siklus II & Siklus III \\
\hline 1. & $\begin{array}{c}\text { Keaktifan Peserta } \\
\text { didik }\end{array}$ & $66,3 \%$ & $75 \%$ & $90,47 \%$ \\
\hline 2. & Jumlah Peserta Didik & 29 & 31 & 33 \\
\hline 3. & $\begin{array}{c}\text { Rata-rata quiss Peserta } \\
\text { didik }\end{array}$ & 69,23 & 86,45 & 90,60 \\
\hline
\end{tabular}

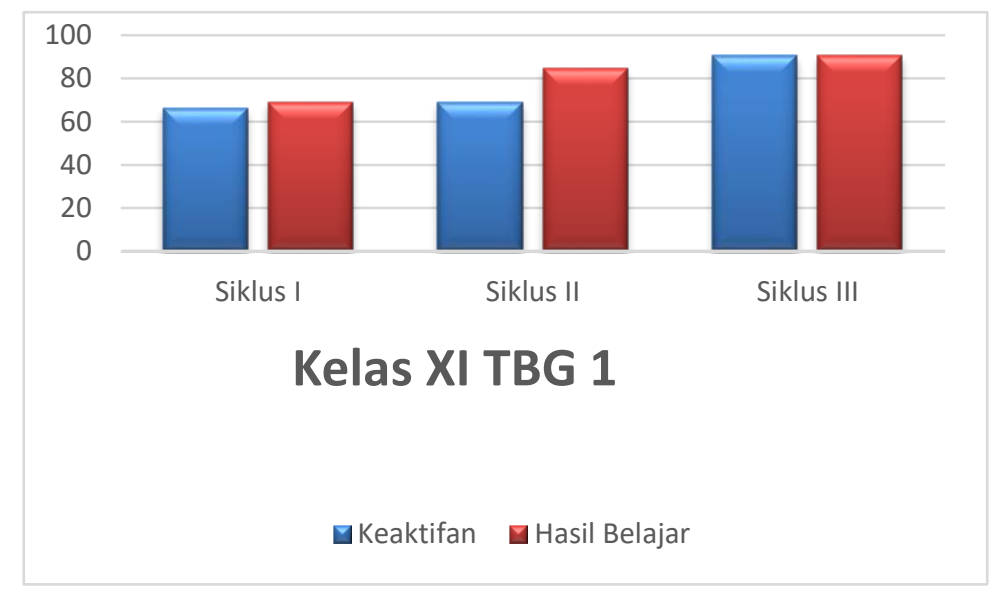

\section{Gambar : Hasil Belajar dan keaktifan}

Berdasarkan pada tabel 4 peningkatan hasil belajar setiap siklus menunjukan peningkatan hasil perhitungan di setiap siklus. Hal tersebut dikarenakan pembelajaran daring menggunakan google classroom, sedangkan peserta didik kurang begitu antusias dan belum terbiasa dalam berdiskusi melalui google classroom. Sehingga untuk pembelajaran online diperlukan model pembelajaran inovatif dengan harapan peserta didik jadi lebih kreatif, berfikir kritis, dalam berdiskusi ataupun dalam pengerjaan soal. Kurangnya waktu dan 
terkendala sinyal serta kendala tekhnis lain (seperti HP rusak, eror ) yang menjadi sedikit hambatan dalam pembelajaran online menggunakan google Classroom. Peserta didik sudah mulai terbiasa dengan pembelajaran online menggunakan google classroom sehingga penggunaan aplikasi google classroom telah memberikan pengaruh yang besar terhadap peningkatan hasil belajar.

Penggunaan aplikasi google classroom cukup efektif untuk melengkapi implementasi dari pendekatan pembelajaran Inovatif. Tahapan implementasi ini telah di sesuaikan dengan pendekatan pembelajaran yang digunakan selama ini, yaitu pendekatan kontekstual dan menuju abad 21 yang menggunakan model pembelajaran Inovatif. Langkah pertama, membuat perangkat mengajar yang telah disesuaikan secara jelas dan dapat dipahami oleh peserta didik, sehingga peserta didik dapat belajar dengan mudah. Kemudian mengunggah perangkat tersebut ke dalam aplikasi google classroom. Perangkat tersebut tentang bahan ajar, media, LKPD pembelajaran matematika dalam bentuk word ataupun pdf dan video tentang pembelajaaran matematika sebagai referensi peserta didik untuk belajar. Di aplikasi google classroom juga disediakan kolom komentar yang bertujuan untuk membuka ruang diskusi antara pengajar dan peserta didik. Sehingga peserta didik dapat berdiskusi dengan mudah tentang materi yang dianggap sulit.

Jadi penggunaan model pembelajaran inovatif seperti Discovery Learning dan Problem Based Learning dapat meningkatnya keaktifan peserta didik dalam menggunakan aplikasi Google Classroom di kelas XI TBG 1 SMK N 3 Jember. Hal ini sependapat dengan pendapat Sudjana (2006: 61) bahwa keaktifan para peserta didik dalam mengikuti proses belajar mengajar dapat dilihat dari beberapa hal yaitu: 1) ketika kegiatan belajar mengajar berlangsung peserta didik turut serta melaksanakan tugas belajarnya, 2) peserta didik mau terlibat dalam pemecahan masalah dalam kegiatan pembelajaran, 3) peserta didik mau bertanya kepada teman atau kepada guru apabila tidak memahami, menemui kesulitan, 4) peserta didik mau berusaha mencari informasi yang dapat diperlukan untuk pemecahan persoalan yang sedang dihadapinya, 5) peserta didik melakukan diskusi kelompok sesuai dengan petunjuk guru, 6) peserta didik mampu menilai kemampuan dirinya dan hasil -hasil yang diperolehnya, 7) peserta didik belatih memecahkan soal atau masalah, 8) peserta didik 
Sevi S Addine : Meningkatkan Keaktifan Peserta Didik Pada Kelas...

memiliki kesempatan menggunakan atau menerapkan apa yang telah diperolehnya dalam menyelesaikan tugas atau persoalan yang dihadapinya.

\section{KESIMPULAN, SARAN DAN REKOMENDASI}

Setelah melakukan penelitian tindakan kelas yang menggunakan tiga tahapan siklus yaitu siklus I, siklus II, dan siklus III maka penelitian ini dapat disimpulkan sebagai berikut penggunaan Google Classroom dapat meningkatkan keaktifan peserta didik dalam pembelajaran online dengan menggunakan model pembelajaran inovatif yang membuat peserta didik berfikir kritis, kolaboratif, komunikatif, kreatif yaitu dengan menggunakan Discovery Learning dan Problem Based Learning materi logika matematika di kelas XI TBG 1 SMK N 3 Jember Kec. Patrang, Kab. Jember. Keaktifan peserta didik dapat ditingkatkan dengan beberapa tindakan seperti berikut:

1. Membuat Rencana Pelaksanan Pembelajaran (RPP) dengan model pembelajaran Discovery Learning dan Problem Based Learning

2. Guru menyediakan perangkat mengajar yang dapat digunakan sebagai literasi dan memberikan alamat situs internet yang dapat digunakan peserta didik dengan mengunggah di Google Classroom

3. Guru harus terus menerus memberikan motivasi kepada peserta didik agar tetap semangat dalam mengikuti pembelajaran online.

Secara umum penggunaan Google Classroom dalam pembelajaran online dalam penelitian ini dapat meningkatkan keaktifan peserta didik yang tentunya efektif diterapkan. Hal ini terlihat pada persentase observasi keaktifan peserta didik seluruh indikator yang semakin meningkat dari siklus I presentase $66,3 \%$ pada siklus II presentase keaktifan peserta didik sebesar $75 \%$ dan pada siklus III presentase keaktifan peseta didik 90,47\%. Hal ini juga diiringi dengan hasil belajar peserta didik yang meningkat. Hasil rata-rata nilai siklus I sebesar 69, rata-rata nilai siklus II sebesar 86,45, dan rata-rata nilai siklus III sebesar 90,60.

Berdasarkan kesimpulan diatas tentang hasil yang ditentukan dalam PTK ini, maka penulis memberikan saran sebagai berikut: 
1. Mendorong dan memberikan motivasi kepada guru untuk selalu berusaha mengembangkan model atau metode pembelajaran baru dengan menerapkan pembelajaran inovatif, sehingga proses dan hasil pembelajaran dapat terus meningkat.

2. Guru berkolaborasi dengan peserta didik untuk lebih sering berkomunikasi menggunakan Google Classroom.

3. Mengingat penelitian tindakan yang telah dilakukan ini masih terdapat kekurangan, oleh sebab itu sebaiknya dilakukan penelitian yang lebih lanjut sehingga dapat melengkapi kekurangan yang ada pada penelitian sekarang.

\section{UCAPAN TERIMAKASIH}

Oleh karena itu pada kesempatan ini penulis ingin menyampaikan rasa terimakasih kepada:

- Bapak Agus Budiarto,S.P.,M.Pd, selaku Kepala SMKN 3 Jember yang telah memberikan ijinnya kepada saya untuk dapat mengikuti Pendidikan Profesi Guru dan telah memberikan ijin untuk dapat melaksanakan penelitian tindakan kelas di sekolahan.

- Ibu Fatimatul Khikmiyah, M.Sc., Ibu Dr. Sri Uchtiawati, M.Si., Bapak Dr. Sarwo Edy, M.Pd., Bapak Dr. Irwani Zawawi, M.Kes., Ibu Nur Fauziyah, M.Pd., Bapak Syaiful Huda, M.Si. selaku Dosen Pengampu Pendidikan Profesi Guru di Universitas Muhammadiyah Gresik.

- Bapak Drs. Dzulkifli Efendi, M.Pd. selaku Guru Pembimbing.

- Saudara seperjuangan PPG Dalam Jabatan Tahap 12020 di Universitas Muhammadiyah Gresik Provinsi Jawa Timur yang selalu berjuang bersama.

- Keluarga tercinta yang selalu memberikan doa dan semangatnya selama proses pelaksanaan dan pembuatan laporan penelitian tindakan kelas.

- Semua pihak yang telah membantu dalam penyusunan Laporan Penelitian Tindakan Kelas ini.

\section{DAFTAR PUSTAKA}

Arikunto, S. (2006). Prosedur Penelitian Suatu Pendekatan. Yogyakarta: PT Rineka Cipta. D. P. (2020, 10 28). Pengertian Hasil Belajar Menurut Para Ahli. Retrieved from hasilbelajar: https://www.dosenpendidikan.co.id/hasil 
Sevi S Addine : Meningkatkan Keaktifan Peserta Didik Pada Kelas...

Fathur. (2020, Februari 10). STEAM Sebuah Pendekatan Pembelajaran Abad 21. Retrieved from steam-sebuah-pendekatan-dalam: $\quad$ http://www.fathur.web.id/2020/02/steamsebuah-pendekatan-dalam.html

Huda, F. A. (2018, Februari 21). Pengertian Keaktifan Belajar. Retrieved from pengertiankeaktifan-belajar: http://fatkhan.web.id/pengertian-keaktifan-belajar/

Mariani, S. (2019). Pendalaman Materi Matematika Modul 4 Kombinatorik dan Statistika. Semarang: Kemdikbud.

Markaban. (2008). Model Penemuan Terbimbing pada Pembelajaran Matematika SMK. Yogyakarta: Pusat Pengembangan dan Pemberdayaan Pendidik dan Tenaga Kependidikan Matematika.

Salirawati. (2011). Teknik Analisis Data dalam PTK. Yogyakarta: Sleman.

Sifa, R. (2015, Juni 17). Sampling Purposive (Pengumpualan data). Retrieved from sampling-purposive-pengumpualan-data:

https://www.kompasiana.com/rosifa/55608913c523bd6b49ff3cla/sampling-purposivepengumpualan-data.

Sudjana, N. (2006). Hasil dan Proses Belajar Mengajar. Bandung: Remaja Rosdakarya. 